\title{
Applied Entomology and Zoology Vol. 50, No. 1 目次
}

(2015 年 2 月 25 日発行)

\section{EDITORIAL}

Message from the Chief Editor

T. Gotoh 1

[編集委員長続投にあたって

後藤哲雄 $] 1$

\section{ORIGINAL RESEARCH PAPERS}

Development of Bradysia odoriphaga (Diptera: Sciaridae) as affected by humidity: an age-stage, two-sex, life-table study Y. Yang $\cdot$ W. Li $\cdot$ W. Xie $\cdot \mathrm{Q} . \mathrm{Wu} \cdot \mathrm{B} . \mathrm{Xu} \cdot \mathrm{S}$. Wang $\cdot \mathrm{C}$. $\mathrm{Li} \cdot \mathrm{Y}$. Zhang 3

[クロバネキノコバエ科の一種 Bradysia odoriphaga（ハエ目：クロ バネキノコバエ科) の生活史特性に及ぼす湿度の影響

Yuting Yang $\cdot$ Wenxiang $\mathrm{Li} \cdot$ Wen Xie $\cdot$ Qingjun Wu Baoyun Xu Shaoli Wang $\cdot$ Chuanren Li $\cdot$ Youjun Zhang] 3

The additive effect of carbon dioxide on mortality of the cigarette beetle Lasioderma serricorne (Coleoptera: Anobiidae) in low-oxygen atmospheres

T. Imai 11

[タバコシバンムシ Lasioderma serricorne (コウチュウ目：シバン ムシ科) の低酸素殺虫に対する二酸化炭素添加効果

今井利宏] 11

Role of scalloped in the post-embryonic development of the red flour beetle Tribolium castaneum (Coleoptera: Tenebrionidae)

C. Minakuchi - T. Ohde $\cdot$ K. Miura • T. Tanaka • T. Niimi 17 [コクヌストモドキ Tribolium castaneum (コウチュウ目：ゴミムシ ダマシ科) の後胚発生における scalloped の役割

水口智江可 · 大出高弘 · 三浦 健 - 田中利治 - 新美輝幸 $] 17$

Occurrence of Trissolcus basalis (Hymenoptera, Platygastridae), an egg parasitoid of Nezara viridula (Hemiptera, Pentatomidae), in Japan

T. Mita $\cdot$ H. Nishimoto $\cdot$ N. Shimizu $\cdot$ N. Mizutani 27

[日本より見出されたミナミアオカメムシ Nezara viridula（カメム シ目，カメムシ科) の卵寄生蜂, Trissolcus basalis (八チ目, 八ラ ビロクロバチ科)

三田敏治・西本浩之・清水信孝・水谷信夫 $] 27$

Relationship between pine wilt disease development in asymptomatic carrier trees of Bursaphelenchus xylophilus (Nematoda: Apelenchoididae) and their use by Monochamus alternatus (Coleoptera: Cerambycidae)
N. Maehara $\cdot$ T. Aikawa $\cdot$ N. Kanzaki 33

[マツノザイセンチュウ Bursaphelenchus xylophilus (線形動物門 :

アフェレンコイデス科) の潜在感染木に打けるマツ材線虫病の病

徵進展とマッノマダラカミキリMonochamus alternatus (コウチュ ウ目：カミキリムシ科)によるそれらの木の利用の関係

前原紀敏・相川拓也・神崎菜摘] 33

Adaptive significance of the mating of autumn-morph females with non-overwintering summer-morph males in the Japanese Common Grass Yellow, Eurema mandarina (Lepidoptera: Pieridae)

T. Konagaya $\cdot$ M. Watanabe $\mathbf{4 1}$

[成虫越冬するキタキチョウ Eurema mandarina (チョウ目：シロ チョウ科) の秋型雌が越冬しない夏型雄と交尾する意義

小長谷達郎・渡辺 守］ 41

Large variation in length of egg period in Psacothea hilaris (Coleoptera: Cerambycidae)

M. Yumino K. Togashi 49

[キボシカミキリPsacothea hilaris (コウチュウ目:カミキリムシ科)

における卵期の長さの大きな変異

弓野瑞穂・富樫一已] 49

Deletion analysis of a superoxide dismutase gene of Bombyx mori (Lepidoptera: Bombycidae) nucleopolyhedrovirus

S. Katsuma $\cdot$ H. Bando • T. Shimada 57

[カイコBombyx mori (チョウ目：カイコガ科) 核多角体病ウイル スの superoxide dismutase 遺伝子久損株の解析

勝間 進·伴戸久徳 · 嶋田 透] 57

De novo analysis of the Tenebrio molitor (Coleoptera: Tenebrionidae) transcriptome and identification of putative glutathione $\mathrm{S}$-transferase genes

S. Liu - X.-X. Shi • Y.-D. Jiang - Z.-J. Zhu • P. Qian - M.-J. Zhang $\cdot$ H. Yu ' Q.-Z. Zhu 'Z.-J. Gong - Z.-R. Zhu 63

[チャイロコメノゴミムシダマシ Tenebrio molitor (コウチュウ目 : ゴミムシダマシ科) の de novo トランスクリプトーム解析と glutathione S-transferase 候補遺伝子群の同定

$\mathrm{Su}$ Liu $\cdot$ Xiao-Xiao Shi $\cdot$ Yan-Dong Jiang $\cdot$ Zi-Jie Zhu $\cdot$ Ping Qian Min-Jing Zhang $\cdot$ Hang Yu $\cdot$ Qing-Zi Zhu $\cdot$ Zhong-Jun Gong $\cdot$ ZengRong Zhu] 63

Genetic structure in relation to reproduction mode in Thrips tabaci (Insecta: Thysanoptera)

K. Sogo K. Miura M. Aizawa $\cdot$ T. Watanabe $\cdot$ R. 
Stouthamer $\mathbf{7 3}$

[ネギアザミウマ (昆虫綱 : アザミウマ目) の生殖様式と遺伝的構造 十川和士 · 三浦一芸 · 相澤美里 - 渡邊文夫 · Richard Stouthamer] 73

Influence of leaf trichome type and density on the host plant selection by the greenhouse whitefly, Trialeurodes vaporariorum (Hemiptera: Aleyrodidae)

P. B. Avery • V. Kumar • M. S. J. Simmonds • J. Faull 79

[オンシッコナジラミ Trialeurodes vaporariorum (カメムシ目 : コナジ ラミ科)による寄主植物選択に及ぼすトリコームタイプとその密度

Pasco B. Avery · Vivek Kumar - Monique S. J. Simmonds · Jane Faull] 79

Effects of manipulated density of the wolf spider, Pardosa astrigera (Araneae: Lycosidae), on pest populations and cabbage yield: a field enclosure experiment

H. Suenaga • T. Hamamura 89

[ウヅキコモリグモ Pardosa astrigera (クモ目：コモリグモ科) の 密度操作がキャベッの害虫個体群と収量に及ぼす影響：ほ場にお ける囲い込み試験

末永 博 · 浜村徹三] 89

Indirect effects of nutrients in organic and conventional paddy field soils on the rice grasshopper, Oxya japonica (Orthoptera: Acrididae), mediated by rice plant nutrients D. W. Trisnawati $\cdot$ T. Tsukamoto $\cdot$ H. Yasuda 99

[有機及び慣行水田土䁃がイネの養分を通じハネナガイナゴ Oxya japonica (バッタ目：バッタ科) の個体数と発育に及ぼす間接効果 Dina Wahyu Trisnawati・塚本敬之・安田弘法］ 99

Analysis of an antennal cDNA library and the expression patterns of two olfactory genes in Frankliniella occidentalis (Thysanoptera: Thripidae)

F.-F. Zeng • S.-S. Zhou • Y.-H. Ding • M.-Q. Wang 109

[ミカンキイロアザミウマ Frankliniella occidentalis（アザミウマ目：

アザミウマ科) の触角由来 cDNA ライブラリ解析と嗅覚関連遺伝 子の発現パターン

Fang-Fang Zeng $\cdot$ Shuang-Shuang Zhou $\cdot$ Yan-Hong Ding $\cdot$ Man-Qun Wang] 109

Nutritional status of overwintering adults of the brown marmorated stink bug, Halyomorpha halys (Hemiptera: Pentatomidae), is affected by cone counts of Japanese cedar, Cryptomeria japonica, in northern Japan

K. Funayama 117

[北日本でクサギカメムシ Halyomorpha halys（カメムシ目：カメ
ムシ科) 越冬成虫の栄養状態はスギ球果量に影響される

舟山 健] 117

Benomyl-resistant Beauveria bassiana (Hypocreales: Clavicipitaceae) mutants induced by ion beams

Y. Fitriana S. Shinohara K. Satoh I. Narumi $\cdot$ T. Saito 123

[イオンビーム照射によるべノミル耐性 Beauveria bassiana（ヒポ クレア目：バッカクキン科) 変異体の作出

Yuyun Fitriana ·篠原 忍・佐藤勝也・鳴海一成 ·西東 力] 123

\section{TECHNICAL NOTES}

Development and characterization of microsatellite loci from Metcalfa pruinosa (Hemiptera: Flatidae)

M. Kim • D. H. Kwon · H. Kim · S. Lee 131

[アオバハゴロモ科の一種 Metcalfa pruinosa（カメムシ目：アオバ ハゴロモ科) のマイクロサテライト座位の開発と評価

Minyoung Kim · Deok Ho Kwon · Hyojoong Kim · Seunghwan Lee ] 131

Novel behavioral assay of wasabi avoidance in Drosophila melanogaster (Diptera: Drosophilidae) using a video tracking system

H. Ohashi • T. Sakai 137

[キイロショウウジョウバエ Drosophila melanogaster (ハエ目:ショ

ウジョウバエ科) に拈けるビデオトラッキングシステムを用いた

ワサビ忌避の新規行動アッセイ

大橋ひろ乃・坂井貴臣］ 137

Construction of Adoxophyes honmai nucleopolyhedrovirus bacmid DNA by using a gene-repair BAC cassette

Y. Saito · Y. Kunimi • M. Nakai 143

[遺伝子修復 BAC カセット法を用いたチャノコカクモンハマキ核 多角体病ウイルスバクミドDNAの構築

齋藤康将・国見裕久・仲井まどか] 143

\section{ERRATUM}

Erratum to: Rapid microsatellite marker isolation for the pink stem borer, Sesamia inferens (Lepidopetera: Noctuidae) through 454 GS-FLX Titanium pyrosequencing of enriched DNA libraries and cross amplification in related taxa

Y. Liu • X. An • M. Hou 147

[訂正：イネヨトウ Sesamia inferens（チョウ目：ヤガ科）における ロシュ 454 シーケンサーを用いた高速マイクロサテライトマー カー探索と近縁分類群に打ける交差増幅

Yudi Liu $\cdot$ Xingkui An • Maolin Hou $] 147$ 